\title{
SNC80 and naltrindole modulate voltage-dependent sodium, potassium and calcium channels via a putatively delta opioid receptor-independent mechanism
}

\author{
Lucia Moravč́ková ${ }^{1}$, Jana Královičová ${ }^{1}$ and L’ubica Lacinová ${ }^{1,2}$ \\ ${ }^{1}$ Institute of Molecular Physiology and Genetics, Center of Biosciences, Slovak Academy of Sciences, Bratislava, Slovakia \\ ${ }^{2}$ Faculty of Natural Sciences, University of Ss. Cyril and Methodius, Trnava, Slovakia
}

\begin{abstract}
SNC80 was designed as a highly selective nonpeptide delta opioid receptor (DOR) agonist. Antidepressant-like and antinociceptive effects of this compound were demonstrated in animal models. Naltrindole was synthetized as a highly selective DOR antagonist. Its antitussive and antinociceptive effects were reported. Observed effects of SNC80 and naltrindole may be accompanied by changes in neuronal excitability including modulation of voltage-dependent ion channels. We investigated possible DOR-independent modulation of neuronal sodium, calcium and potassium currents by both agents. NG108-15 cells lacking expression of DOR protein were used as model of neuronal cells. Cells were differentiated into neuronal phenotype by exposure to dibutyryl cyclicAMP (dbcAMP). Lack of DORs expression in NG108-15 cells and the presence of DOR expression in brain and neuronal cultures were demonstrated by Western blot analysis. Both SNC80 and naltrindole exerted low to moderate modulatory effects on voltage-dependent ion currents. SNC80 weakly inhibited sodium current, potentiated calcium current, and did not act on potassium channels. Naltrindole inhibited sodium current, did not act on calcium current and inhibited potassium current at a high concentration. Such effects should be taken into account when these compounds are used for investigation of DOR-mediated signaling pathways.
\end{abstract}

Key words: NG108-15 cells - Naltrindole - SNC80 - Sodium current - Potassium current Calcium current - Opioid receptors

\section{Introduction}

NG108-15 cell line is a hybrid of mouse neuroblastoma (N18TG-2) and rat glioma (C6BU-1) cell lines (Hamprecht 1977). These cells have been used as a model for cholinergic neurons (McGee et al. 1978; Schanne et al. 1989; Jin et al. 1994; Chemin et al. 2002). Serum-starved cells in the presence of dibutyryl cyclic-AMP (dbcAMP) start to develop neurites, express neuronal proteins, and develop neuronal morphology (Tojima et al. 2000). Further, differentiation involves biochemical and electrophysiological changes, such as an increase of sodium or calcium currents densities.

Correspondence to: Lubica Lacinova, Institute of Molecular Physiology and Genetics, Center of Biosciences, Slovak Academy of Sciences, Bratislava, Slovakia

E-mail: lubica.lacinova@savba.sk
Increase of sodium (Liu et al. 2012a) and calcium (Liu et al. 2012b) currents was observed after 9 days of differentiation. Sodium channels in neuronal cells are classified as tetrodotoxin (TTX)-sensitive and TTX-resistant (Roy and Narahashi 1992). In differentiated NG108-15 cells TTXsensitive sodium channels are solely expressed and are predominantly of $\mathrm{Na}_{\mathrm{V}} 1.7$ subtype (Kawaguchi et al. 2007; Liu et al. 2012a). All classes of voltage-dependent calcium channels are expressed in differentiated NG108-15 cells. Density of low-voltage-activated (T-type) calcium currents did not differ in undifferentiated and differentiated cells. Expression of high-voltage-activated calcium channels was markedly enhanced in differentiated cells (Lukyanetz 1998; Chemin et al. 2002; Liu et al. 2012b). NG108-15 cells also express multiple potassium channels. Expression of inwardrectifier potassium channel $\left(\mathrm{K}_{\mathrm{ir}}\right)$ was markedly increased during differentiation, in accord with more hyperpolarized 
resting membrane potential (Hu and Shi 1997; Ma et al. 1999; Pancrazio et al. 1999).

NG108-15 cells were frequently used for characterization of regulatory pathways related to opioid receptors (Lee et al. 1988; Loh and Smith 1990). In recent years, $\delta$-opioid receptors (DOR) and their ligands are in center of interest due to their potential role in treatment of chronic pain and mood disorders (Gaveriaux-Ruff et al. 2008; Fujii et al. 2013). Previously, NG108-15 cells have been used as a model for studying of DOR (Roerig et al. 1992; Heiss et al. 2009) and DORs were cloned for the first time from these cells (Evans et al. 1992; Kieffer et al. 1992). However, expression of these receptors is very unstable and at higher passage number cells express little or no receptors (Vicente-Sanchez et al. 2016).

Nonpeptide compound (+)-4-[( $\alpha R)-\alpha-((2 S, 5 R)-4-$ Allyl-2,5-dimethyl-1-piperazinyl)-3-methoxybenzyl]- $N, N$ diethylbenzamide (SNC80) was designed as a highly selective DOR agonist (Calderon et al. 1994, 1997). Nevertheless, recent study demonstrated highest affinity of this compound to $\mu-\delta$ heteromers (Metcalf et al. 2012). SNC80 is commonly used in research focused on outcomes of an activation of DOR-related pathways. SNC80 had antidepressant-like effect in rats, which was blocked by the selective DOR antagonist naltrindole, indicating that this effect is specific to DOR signaling pathway (Jutkiewicz et al. 2003, 2004). In monkeys this compound produced an antinociceptive effect (Negus et al. 1998; Allen et al. 2002). High doses of SNC80 produced proconvulsant activity in rats (Bausch et al. 2005) and mice (Chung et al. 2015). Opioid receptors-independent effects of SNC80 were demonstrated, as well. In granular cells of dentate gyrus, SNC80 directly interacted with voltage-dependent sodium channels (Remy et al. 2004).

Nonpeptide ligand, 17-cyclopropylmethyl-6,7-dehydro4,5a-epoxy-3,14-dihydroxy-6,7,2',3' -indolomorphinan (naltrindole) was synthetized as a highly selective DOR antagonist (Portoghese et al. 1988). It was commonly used as a tool to prove that a DOR agonists act through DOR signaling pathways (Bilecki et al. 2000; Jutkiewicz et al. 2004; Remy et al. 2004). However, it was found that naltrindole itself has antinociceptive (Takemori et al. 1992) and antitussive (Kamei et al. 1995) effect when applied without agonist pretreatment. Antinociceptive effect is probably mediated through $\kappa$-opioid receptors (KOR) (Takemori et al. 1992), while antitussive effect of naltrindole is mediated partially through DOR and partially through KORs (Kamei et al. 1995).

Observed effects of DOR ligands may be accompanied by changes in neuronal excitability including modulation of voltage-dependent ion channels. Indeed, we have observed such changes in primary culture of hippocampal neurons (Moravcikova and Lacinova, unpublished data). We aimed to elucidate whether a DOR-independent pathways are involved in modulation of neuronal excitability by SNC80 and naltrindole. NG108-15 cell line used in our laboratory does not express DOR protein. Therefore, we used these cells as a model for testing DOR-independent effects of both ligands an agonist SNC80 and an antagonist naltrindole, on neuronal voltage-gated sodium, calcium, and potassium channels.

\section{Material and Methods}

\section{Cell cultivation}

Differentiated NG108-15 cell line was used in all experiments. NG108-15 cell line was kindly provided by N. Klugbauer from Albert-Ludwig University in Freiburg, Germany. Cells were incubated at $37^{\circ} \mathrm{C}$ in humidified atmosphere containing 5\% $\mathrm{CO}_{2}$. DMEM medium with high glucose supplemented with $10 \%$ fetal bovine serum (FBS), $100 \mathrm{IU} / \mathrm{ml}$ penicillin, $100 \mu \mathrm{g} / \mathrm{ml}$ streptomycin and $5 \mu \mathrm{g} / \mathrm{ml}$ Plasmocin prophylactic (Invitrogen) was used as a culture medium. For experiments cells were seeded on coverslips (Sarstedt, Slovakia) covered by poly-L-lysine (PLL, $50 \mu \mathrm{g} / 1 \mathrm{ml} / 1 \mathrm{~cm}^{2}$ ) in density $1.5 \times 10^{4}$ cells $/ \mathrm{cm}^{2}$. Differentiation was induced by adding $1 \mathrm{mM}$ dbcAMP into culture medium without FBS. After 7 to 11 days of conditioning, cells were used for electrophysiological experiments and molecular analysis. Unless mentioned otherwise, all chemicals were purchased from Sigma Aldrich, Slovakia.

\section{Molecular analysis}

Dissected brain tissues from newborn rat were snap-frozen by immersing in liquid nitrogen. For protein extraction, brain tissue was lysed in ice-cold lysis buffer RIPA (150 mM $\mathrm{NaCl}, 1 \% \mathrm{NP}-40,0.5 \%$ deoxycholate, $0.1 \%$ SDS, $50 \mathrm{mM}$ Tris, $\mathrm{pH} 8.0$ ), homogenized and centrifuged at $16000 \times g$ for 10 min at $4^{\circ} \mathrm{C}$ to collect the supernatant. Cell cultures were washed twice with PBS and lysed in RIPA buffer. 40 or $80 \mu \mathrm{g}$ of protein lysates were loaded on 10\% SDS-PAGE gels and transferred to PVDF (Amersham) membranes. The membranes were incubated with mouse anti-delta-type Opioid Receptor (Millipore, MABN352), rabbit anti-Mu Opioid Receptor (Millipore, AB1580-I) and rabbit anti-GAPDH (Santa Cruz, SC-25778) antibodies and appropriate horseradish peroxidase-conjugated secondary antibodies (Santa Cruz). Protein bands were detected using the Immun-Star WesternC Chemiluminescence-Kit (Biorad) according to the manufacturer's instructions.

\section{Electrophysiology}

Sodium $\left(\mathrm{I}_{\mathrm{Na}}\right)$, calcium $\left(\mathrm{I}_{\mathrm{Ca}}\right)$ and potassium $\left(\mathrm{I}_{\mathrm{K}}\right)$ currents were measured by whole cell patch clamp using HEKA EPC10 amplifier (HEKA Electronics, Lambrecht, Germany). 
Patch pipettes were made from borosilicate glass (Sutter Instruments, Novato, CA). When filled with experimental solutions their resistance was 4-5 M $\Omega$. For measurements of $\mathrm{I}_{\mathrm{Na}}$ bath solution containing (in $\mathrm{mM}$ ): $105 \mathrm{NaCl}, 10$ HEPES, $2 \mathrm{CaCl}_{2}, 0.5 \mathrm{MgCl}_{2}, 25 \mathrm{TEA}-\mathrm{Cl}$, and 10 D-glucose; $\mathrm{pH} 7.4$ (adjusted with $\mathrm{NaOH}$ ) was used. Pipette solution contained (in mM): $3 \mathrm{Na}_{2} \mathrm{ATP}, 10 \mathrm{HEPES}, 3 \mathrm{EGTA}, 2 \mathrm{MgCl}_{2}, 135 \mathrm{CsCl}$, $0.4 \mathrm{Na}_{2} \mathrm{GTP}$, and 20 TEA-Cl; pH 7.4 (adjusted with $\mathrm{CsOH}$ ). $\mathrm{I}_{\mathrm{Ca}}$ was measured using bath solution containing (in $\mathrm{mM}$ ): $10 \mathrm{HEPES}, 10 \mathrm{BaCl}_{2}, 1 \mathrm{MgCl}_{2}, 140$ TEA-Cl, and $10 \mathrm{D}$-glucose; $\mathrm{pH} 7.4$ (adjusted with TEA-OH). Pipette solution for calcium current contained (in mM): $5 \mathrm{Na}_{2} \mathrm{ATP}, 10$ HEPES, 11 EGTA, $1 \mathrm{CaCl}_{2}, 120 \mathrm{CsCl}, 4 \mathrm{MgATP}$, and 4 Tris-GTP; pH 7.3 (adjusted with $\mathrm{CsOH}$ ). For measurements of $\mathrm{I}_{\mathrm{K}}$ bath solution contained (in $\mathrm{mM}$ ): $130 \mathrm{NaCl}, 3 \mathrm{KCl}, 10 \mathrm{HEPES}$, $2 \mathrm{CaCl}_{2}, 1 \mathrm{MgCl}_{2}$, and $10 \mathrm{D}$-glucose; $\mathrm{pH} 7.4$ (adjusted with $\mathrm{NaOH}$ ); and pipette solution contained (in $\mathrm{mM}$ ): $120 \mathrm{~K}$ gluconate, $2 \mathrm{Na}_{2} \mathrm{ATP}, 10 \mathrm{HEPES}, 20 \mathrm{KCl}, 2 \mathrm{MgCl}_{2}$, and 0.25 $\mathrm{Na}_{2} \mathrm{GTP}$; pH 7.4 (adjusted with $\mathrm{KOH}$ ). Osmolarity of pipette solutions was approximately 290-300 mOsm. Osmolarity of bath solutions was approximately $2-3$ mOsm lower than osmolarity of corresponding pipette solution. $\mathrm{I}_{\mathrm{Ca}}$ and $\mathrm{I}_{\mathrm{K}}$ were measured in the presence of $1 \mu \mathrm{M}$ TTX citrate (Abcam, UK) to block the $\mathrm{I}_{\mathrm{Na}}$.

Sodium currents were activated by $5 \mathrm{~ms}$ long depolarizing pulses to voltages between $-70 \mathrm{mV}$ and $+70 \mathrm{mV}$ from a holding potential of $-90 \mathrm{mV}$. Calcium currents were activated by $50 \mathrm{~ms}$ long depolarizing pulses to voltages between $-40 \mathrm{mV}$ and $+50 \mathrm{mV}$ from a holding potential of $-40 \mathrm{mV}$. Potassium currents were activated by $400 \mathrm{~ms}$ long depolarizing pulses to voltages between $-40 \mathrm{mV}$ and $+80 \mathrm{mV}$ from a holding potential of $-80 \mathrm{mV}$.

\section{Ligands}

Naltrindole hydrochloride (Sigma Aldrich, Slovakia) was dissolved in water in $10 \mathrm{mM}$ concentration. SNC80 (Sigma Aldrich, Slovakia) was dissolved in $1 \mathrm{M} \mathrm{HCl}$ in $1 \mathrm{mM}$ concentration. Both compounds were stored at $-20^{\circ} \mathrm{C}$. Before measurements, stock solutions were diluted in a bath solution to a desired concentration $0.1,1,10$ or $100 \mu \mathrm{M}$. pH of solution with SNC80 was adjusted to $\mathrm{pH} 7.4$ with $\mathrm{NaOH}$. Compounds were applied to the close proximity of measured cell by a perfusion system.

\section{Data analysis}

Data were recorded using Patchmaster v2x73.3 (HEKA Electronics, Lambrecht, Germany) and analyzed using Fitmaster v2x73.3 and Origin 8.1 (OriginLab Co., Northampton, MA, USA) software. Results are presented as a mean \pm standard error of mean (SEM). Statistical differences between groups were determined by one-way or two-way analysis of variance (ANOVA) for repeated measures followed by Tukey's post hoc test for multiple comparison by GraphPad InStat 3 (GraphPad Software, Inc.). One-way ANOVA was used for all experiments with SNC80 and experiments with effect of naltrindole on calcium currents. Two-way ANOVA was used for experiments with effect of naltrindole on sodium and potassium currents. Time (before and after naltrindole administration) was considered dependent variable. Concentration of naltrindole was considered independent variable. Probability $p<0.05$ was considered significant.

\section{Results}

\section{Expression of opioid receptors}

We have analyzed the expression of $\mu$-opioid (MOR) and $\delta$-opioid receptors in differentiated NG108-15 cell line, in $\mathrm{SH}-\mathrm{SY} 5 \mathrm{Y}$ cell line, and in tissues from various brain regions. As demonstrated in the Figure 1, NG108-15 expressed MOR but did not express DOR proteins on comparable level.

\section{Moderate inhibition of the sodium currents}

DOR agonist SNC80 moderately inhibited sodium current in differentiated NG108-15 cells $\left(n=7, \mathrm{~F}_{\mathrm{df} 34}=2.603\right.$, $p=0.0613$ ) (Figure 2A). This effect was statistically significant at $1 \mu \mathrm{M}$ concentration only (Figure $2 \mathrm{C}$ ). Similarly, naltrindole only moderately suppressed sodium current $\left(n=7, \mathrm{~F}_{\mathrm{df1} 1,27}=11.24, p=0.0024\right)$. Significant inhibition was observed at $0.1 \mu \mathrm{M}$ and $100 \mu \mathrm{M}$ concentrations (Figure $2 \mathrm{~B}$ and D). Medium concentrations were without any significant effect (Figure 2C and D).
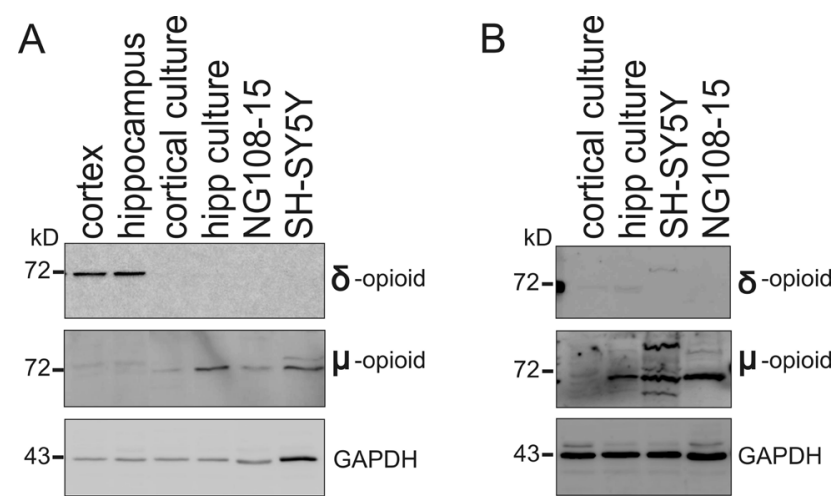

Figure 1. Western blot analysis of homogenized rat brain tissue (cortex, hippocampus), primary cultures of rat hippocampal and cortical neurons, and two immortalized neuron-like cell lines (NG108-15 and SH-SY5Y) with indicated antibodies, using $40 \mathrm{ug}$ (A), or $80 \mathrm{ug}$ (B) of protein lysate. 
Calcium current was potentiated by SNC80

Analysis of voltage-dependent calcium current was hampered by its relatively low amplitude after 7-11 days of differentiation. Therefore, we analyzed only its amplitude activated by a depolarizing pulse to $+10 \mathrm{mV}$, which corresponds to a peak of current-voltage relation. SNC80 significantly potentiated calcium current at all investigated concentrations $\left(n=6, \mathrm{~F}_{\mathrm{df} 29}=24.378, p<0.0001\right)$ (Figure 3A). Naltrindole had dual effect on calcium current - low concentrations
A

SNC80
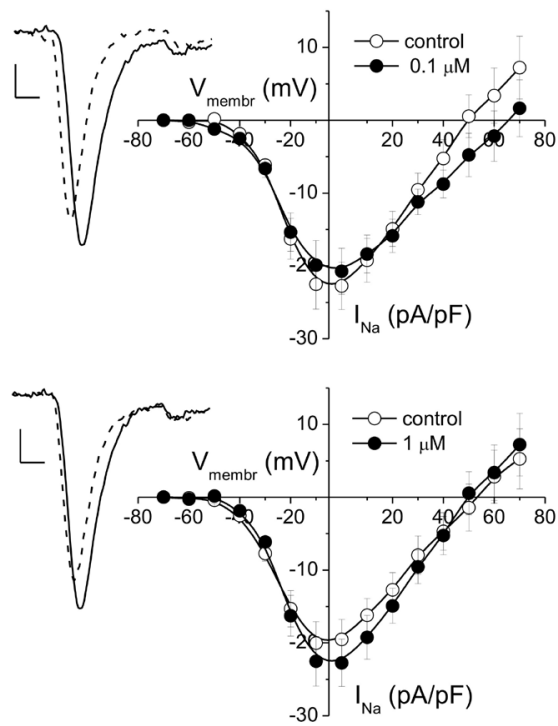

C
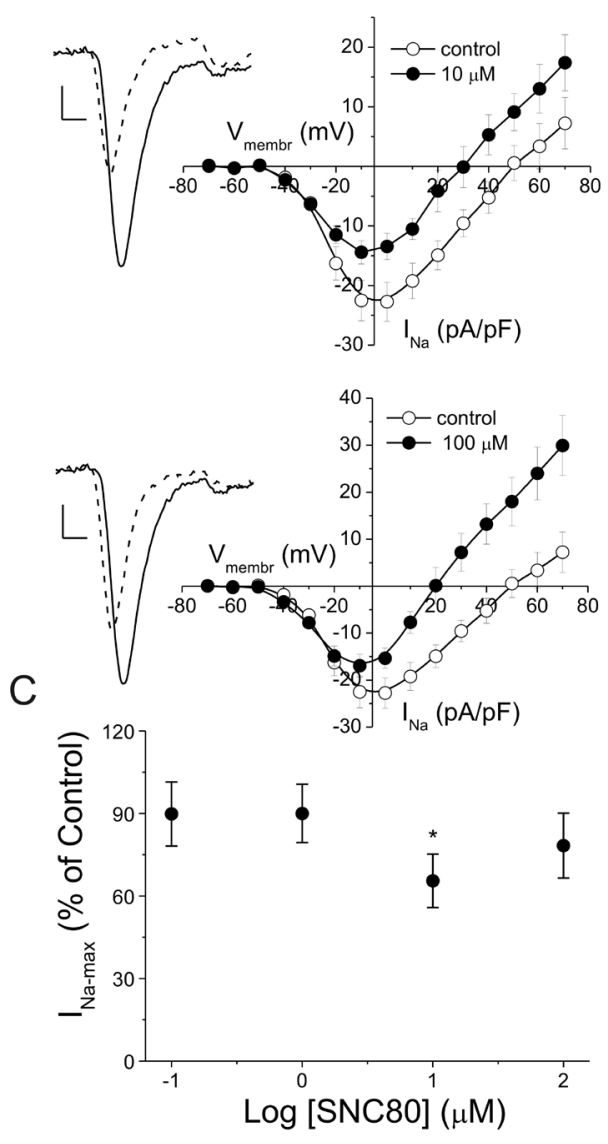

\section{B}
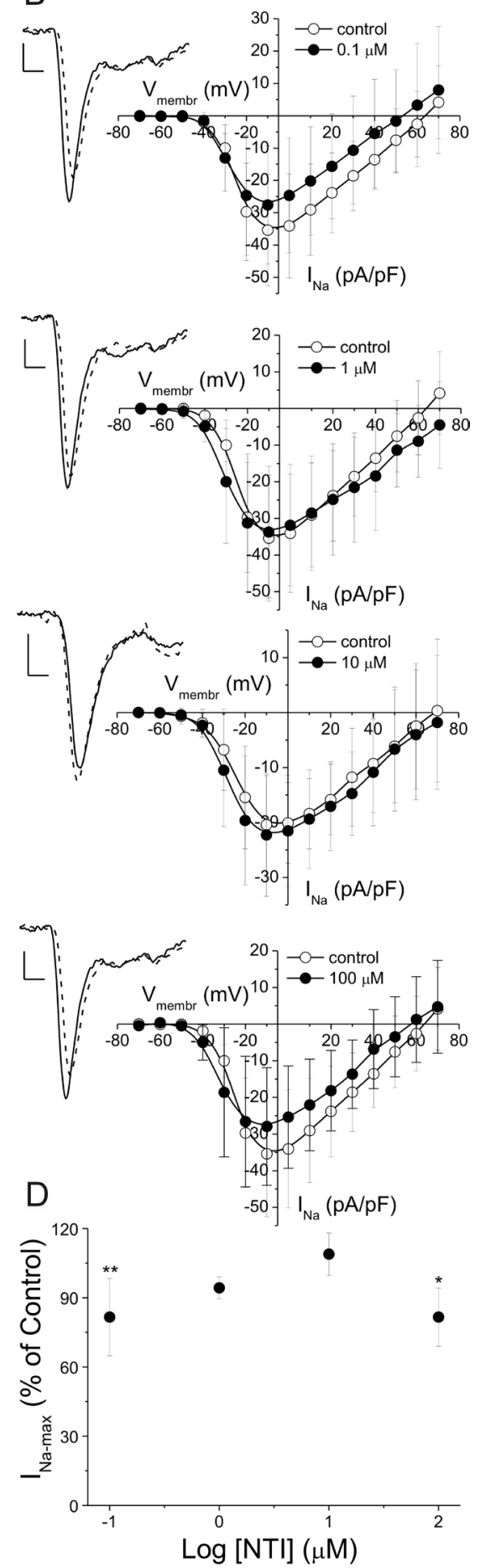

Figure 2. Effects of SNC80 (A) and naltrindole $(\mathbf{B})$ on voltage-gated sodium currents in NG108-15 cell line. Averaged I-V relations for sodium currents were measured before $(O)$ and after $(\bullet)$ drug application in concentrations of 0.1-100 $\mu \mathrm{M}$, as marked in each graph. Representative current traces measured under the control conditions (solid line) and in the drug presence (dashed line) are shown left to the corresponding IV. Concentration-dependences of peak current amplitude in the presence of SNC80 (C) and naltrindole (D) expressed as percentage of control current amplitude (SNC80; $n=7$; naltrindole; $n=7)$. " $n$ " represents the number of individual cells averaged in graphs. NTI, naltrindole; ${ }^{*} p<0.05 ;{ }^{* *} p<$ 0.01 in comparison with control. 
potentiated, and high concentration inhibited the current amplitude (Figure 3B). However, these effects were not significant $\left(n=3, \mathrm{~F}_{\mathrm{df11}}=0.9506, p=0.4609\right)$.

\section{Potassium current was inhibited by naltrindole}

Potassium current in differentiated NG108-15 cells had two components: moderately distinguishable rapidly activating and inactivating component and pronounced noninactivating component. We evaluated separately effects of both compounds on peak potassium current and on sustained potassium current. SNC80 and naltrindole lowered both components of potassium current. Inhibition caused by SNC80 was weak $(n=12$, for peak current: $\mathrm{F}_{\mathrm{df5} 9}=3.214, p=0.0213$; for sustained current: $\left.\mathrm{F}_{\mathrm{df59}}=1.983, p=0.1138\right)$ and only peak current inhibition by $100 \mu \mathrm{M}$ of SNC80 was statistically significant (Figure $4 \mathrm{~A}$ and $\mathrm{B}$ ). Naltrindole was more potent potassium current inhibitor and in $100 \mu \mathrm{M}$ concentration inhibited both peak $\left(n=16, \mathrm{~F}_{\mathrm{df1}, 56}=23.44, p<0.0001\right)$ and sustained $(n=16$, $\left.\mathrm{F}_{\mathrm{df1}, 56}=10.23, p=0.0023\right)$ potassium current with high significance (Figure 4C and D).

\section{Discussion}

In the present work we aimed to characterize effects of the DOR agonist SNC80 and the DOR antagonist naltrindole on neuronal voltage-dependent ion channels in a cellular model lacking DOR protein. SNC80 weakly inhibited sodium current, potentiated calcium current, and did not act on potassium channels. Naltrindole inhibited sodium current, did not act on calcium current and inhibited potassium current at a high concentration.

The diversity of properties for immortalized cell lines from different laboratories were reported (Clementi et al. 1992; Shoji-Kasai et al. 1992; Corradi et al. 1996). We checked our NG108-15 cell line for expression of DOR and MOR. As a positive control DOR and MOR expression in brain tissue and neuronal culture was used. Lack of DOR expression in NG108-15 cell line and high level of MOR protein was confirmed by Western blot analysis. This finding contrasts with older reports which used NG108-15 cells as a model for studying DORs (Roerig et al. 1992; Heiss et al. 2009; Vicente-Sanchez et al. 2016). However, it was also noted that the DOR expression in this cell line is unstable and may be lost after prolonged culturing (Vicente-Sanchez et al. 2016). As properties of immortalized cell lines may change over a long time span, careful examination should be always included into experimental outline.

Effects of SNC80 and naltrindole on voltage-dependent ion channel could be mediated by their binding to another type of opioid receptor, i.e., MOR, KOR, or opioid receptorlike orphan receptor (ORL1). All these receptors are coupled to similar intracellular signaling pathways. Their activation leads to an inhibition of adenylate cyclase activity (Connor and Christie 1999) and an increase phospholipase C activity (Spencer et al. 1997).

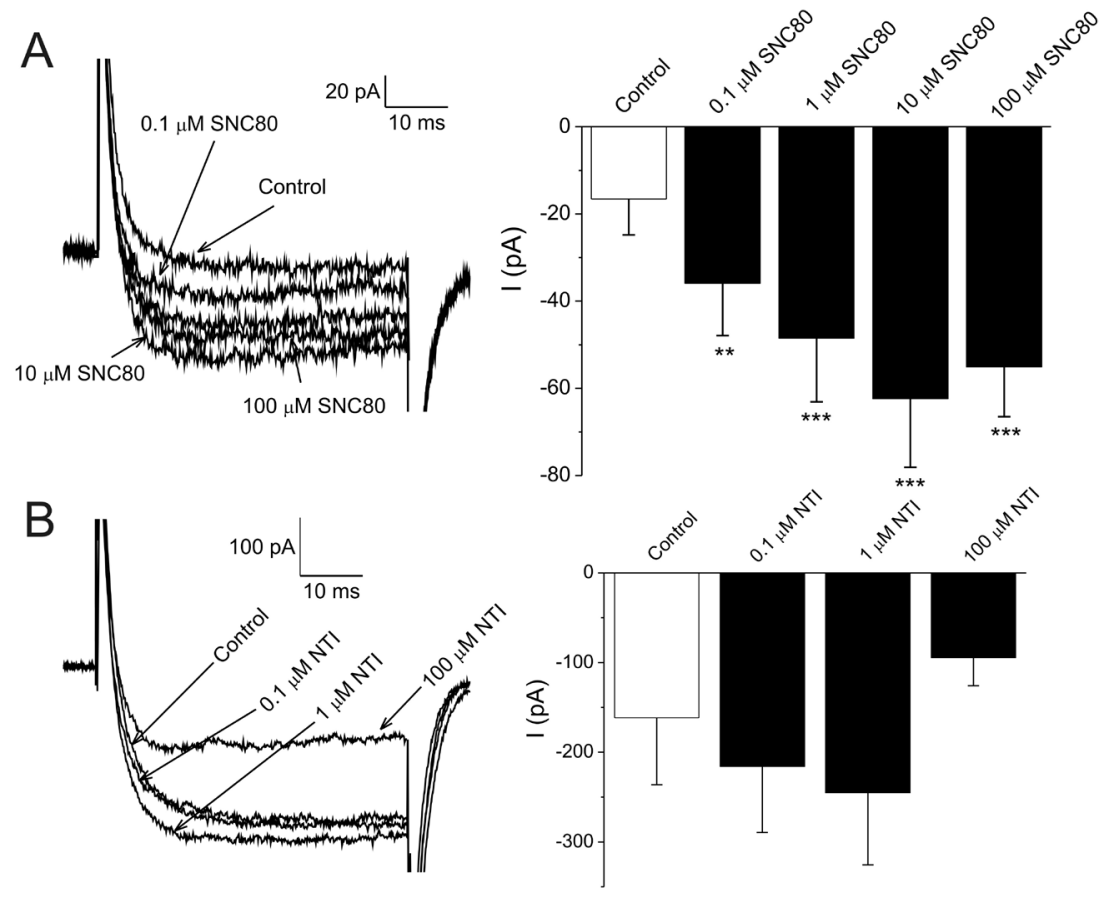

Figure 3. Effects of SNC80 and naltrindole on voltage-gated calcium currents in NG108-15 cell line. A. Left part: Representative current traces recorded under the control conditions and in the presence of SNC80 in concentrations as marked. Right part: Averaged calcium current amplitudes measured at $+10 \mathrm{mV}$ under the control conditions and after application of SNC80 in concentrations $0.1-100 \mu \mathrm{M}$, as marked $(n=6) .{ }^{* *} p<0.01$; ${ }^{* *} p<0.001$ in comparison with control. B. Left part: Representative current traces recorded under the control conditions and in the presence of naltrindole in concentrations as marked. Right part: Averaged calcium current amplitudes measured at $+10 \mathrm{mV}$ under the control conditions and after naltrindole application in concentrations $0.1-100 \mu \mathrm{M}$, as marked $(n=3)$. " $n$ " represents the number of individual cells. NTI, naltrindole. 
In NG108-15 cell line used in our experiments we detected by RT-PCR the expression of ORL1s, while the expression of KORs was negligible (data not shown). SNC80 is not exclusively specific DOR ligand. It was shown to bind effectively to MOR-DOR heteromers, while its binding to MOR itself was weak (Metcalf et al. 2012). Nevertheless, even if SNC80 would be able to activate an alternative opioid receptor pathway in NG108-15 cells, observed effects on voltage-dependent ion currents could not be simply explained by such interaction as they are only partly consistent with previous reports.
Sodium current should be facilitated by OR-activated pathway due to an inhibition of adenylate cyclase activity (Connor and Christie 1999) and, consequently, decrease in channel phosphorylation (Scheuer 2011). We have observed no effect at low concentration and a moderate inhibition at high concentration. Inhibition of sodium current could be caused by a direct interaction of SNC80 with sodium channel. Such interaction was reported also in granular cells of dentate gyrus (Remy et al. 2004). Course of the concentration dependence of sodium current inhibition reported

A

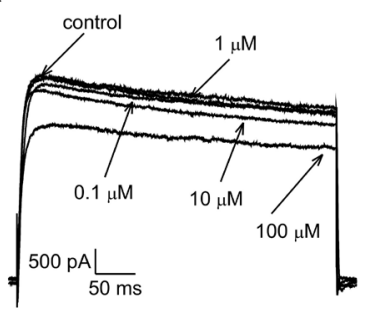

$\mathrm{B}$

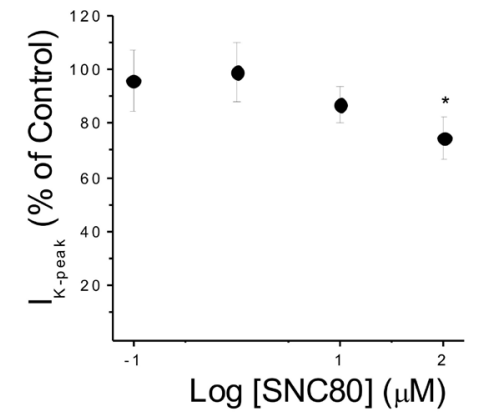

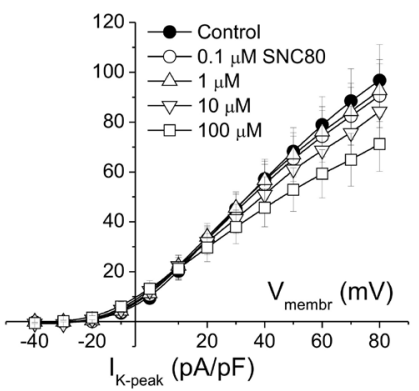
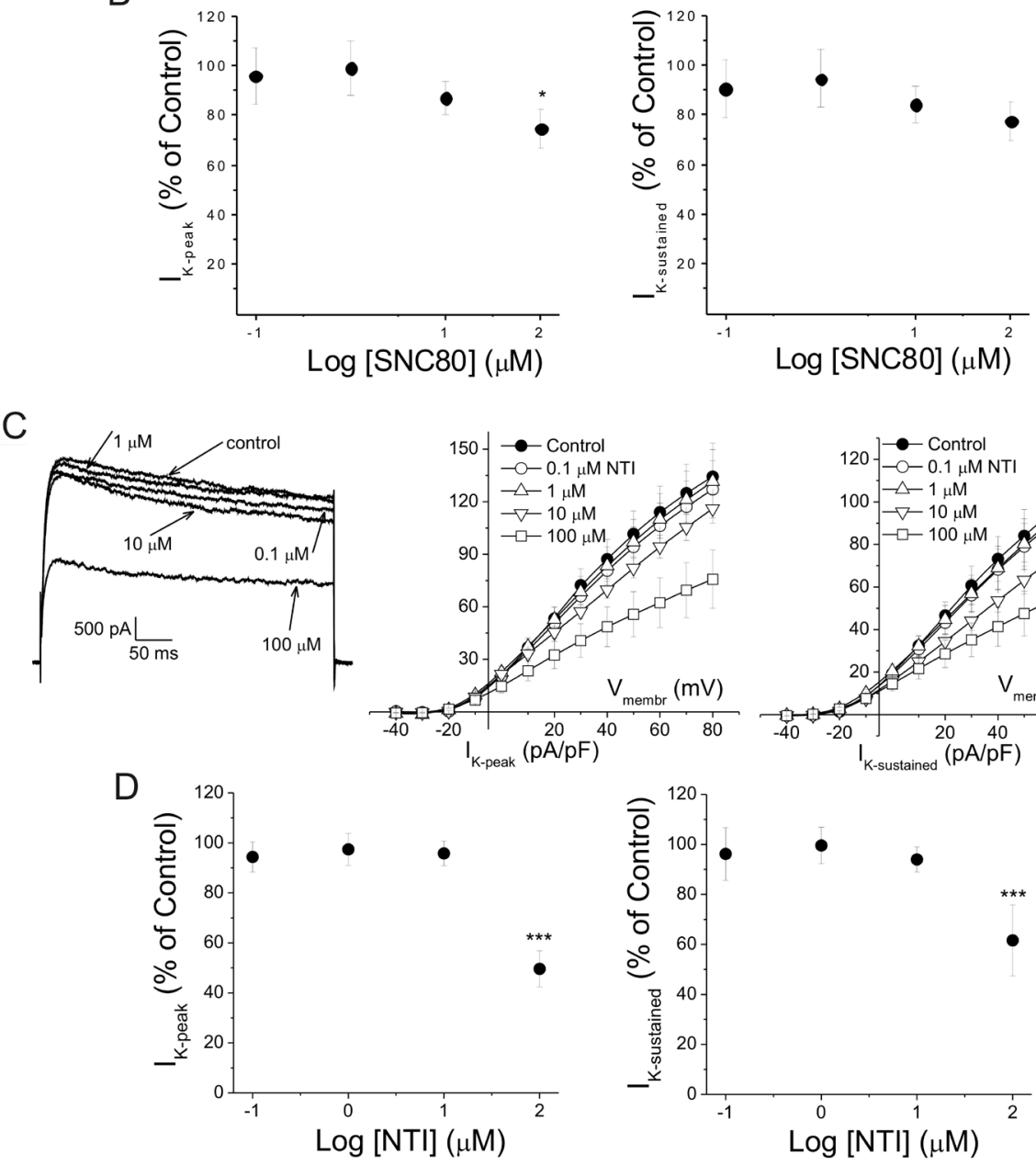
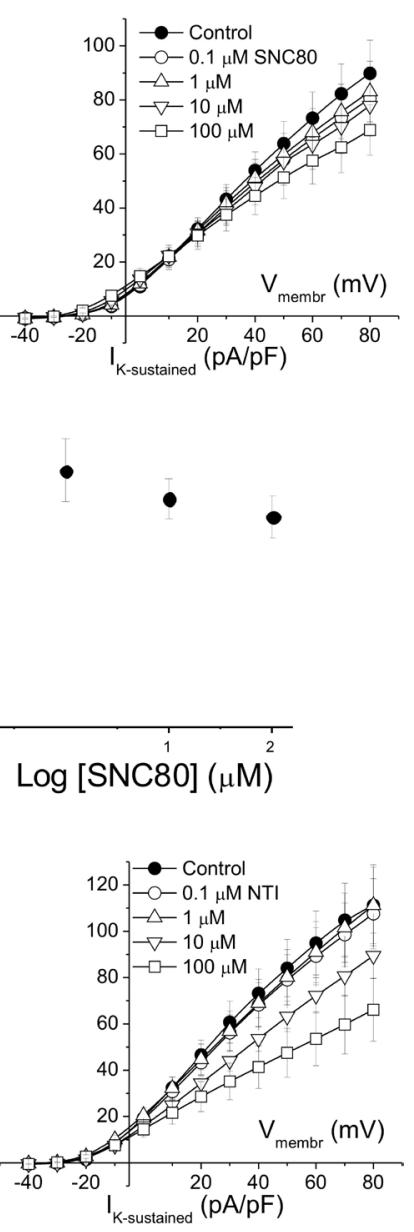

Figure 4. Effects of SNC80 and naltrindole on voltage-gated potassium currents in NG10815 cell line. A. Representative current traces measured under the control conditions and in the presence of SNC80 in concentrations as marked (left), averaged I-V relations for peak (middle) and sustained (right) potassium currents measured before $(\bigcirc)$ and after $(\bullet)$ application of SNC80 in concentrations $0.1-100 \mu \mathrm{M}$, as marked. B. Concentration-dependence of current amplitude measured at $+80 \mathrm{mV}$ in the presence of SNC80 in concentrations $0.1-$ $100 \mu \mathrm{M}$, expressed as percentage of control current amplitude $(n=12) .{ }^{*} p<0.05$ in comparison with control. C. Representative current traces measured under the control conditions and in the presence of naltrindole in concentrations as marked (left), averaged I-V relations for peak (middle) and sustained (right) potassium currents measured before $(\bigcirc)$ and after $(\bullet)$ application of naltrindole in concentrations $0.1-100 \mu \mathrm{M}$, as marked. D. Concentration-dependence of current amplitude measured at $+80 \mathrm{mV}$ in the presence of naltrindole in concentrations 0.1-100 $\mu \mathrm{M}$, expressed as percentage of control current amplitude $(n=16) .{ }^{* * *} p<0.001$ in comparison with control. NTI, naltrindole. 
here could be a result of minor current facilitation due to minor activation of MOR and moderate inhibition by direct interaction with the channel protein.

Facilitation of calcium current is opposite to what we could expect from suppressed adenylate cyclase activity which results in suppressed calcium channel phosphorylation by protein kinase A-dependent mechanism. On the other hand, basal level of calcium current amplitude was very low suggesting very low basal level of channel phosphorylation, which cannot be further decreased by an attenuation of a protein kinase A-related pathway. Observed current enhancement may be related to activation of another signaling pathway, possibly phospholipase C-diacylglyerol-protein kinase C pathway, which is also activated via ORs (Spencer et al. 1997; Fukami et al. 2010). Phosphorylation by protein kinase $\mathrm{C}$ was shown to exert dual effect on neuronal calcium channels (Rajagopal et al. 2014; Rajagopal et al. 2017). Final effect - either inhibition or potentiation - depends on relation between both components.

Effect of SNC80 on potassium current was negligible. The highest tested concentration $100 \mu \mathrm{M}$ slightly but significantly suppressed the peak, but not the sustained current amplitude. This effect may be caused by direct interaction of the drug with the channel protein.

Naltrindole modulated significantly sodium and potassium currents. This drug, like SNC80, does not bind exclusively to DORs. Interaction with KOR (Kamei et al. 1995) and, at micromolar concentration, with ORL1 (Fawzi et al. 1997) was demonstrated. Several naltrindole analogue compounds possessing $\mu$-agonist $/ \delta$-antagonist activities were synthesized (Ananthan et al. 1999). It cannot be excluded that also naltrindole itself may, to a certain extent, possess such properties. The fact that naltrindole reversed morphine effect in cells expressing both MORs and DORs may be also interpreted as an indirect hint that naltrindole may interact not only with DORs but also with MORs (Guo et al. 2015). We can speculate that bell-shaped concentration dependence of naltrindole effect on sodium current may be due to mixed interaction of this drug with MORs and ORL1s. Similar mechanism was demonstrated for another ORs ligand buprenorphine, which exerted bellshaped antinociceptive effect in mice mediated by MORs and modified by ORL1s (Lutfy et al. 2003).

Inhibition of potassium currents by high concentration of naltrindole may be mediated by direct interaction of the drug with channel proteins. Such interpretation is consistent with report that another ORs antagonist naloxone inhibited potassium channels in micromolar concentration and this inhibition was caused by direct channel block (Ulens et al. 1999).

To conclude, both SNC80 and naltrindole may exert low to moderate modulatory effects on sodium, calcium and potassium currents which are independent of their interaction with $\delta$-opioid receptors. Such effects should be taken into account when these compounds are used for investigation of DOR-mediated signaling pathways.

Acknowledgement. Authors wish to thank Emilia Kocurova for excellent technical assistance. NG108-15 cell line was kindly provided by N. Klugbauer from Albert-Ludwig University in Freiburg, Germany. This work was supported by the Slovak Research and Development Agency under the contract No. APVV-15-0388, by grant VEGA $2 / 0107 / 16$, and by ITMS 26230120006 . Authors declare no conflict of interest and no financial interest in the publication of this manuscript.

\section{References}

Allen RM, Granger AL, Dykstra LA (2002): Dextromethorphan potentiates the antinociceptive effects of morphine and the delta-opioid agonist SNC80 in squirrel monkeys. J. Pharmacol. Exp. Ther. 300, 435-441 https://doi.org/10.1124/jpet.300.2.435

Ananthan S, Kezar HS, 3rd, Carter RL, Saini SK, Rice KC, Wells JL, Davis P, Xu H, Dersch CM, Bilsky EJ, Porreca F, Rothman RB (1999): Synthesis, opioid receptor binding, and biological activities of naltrexone-derived pyrido- and pyrimidomorphinans. J. Med. Chem. 42, 3527-3538 https://doi.org/10.1021/jm990039i

Bausch SB, Garland JP, Yamada J (2005): The delta opioid receptor agonist, SNC80, has complex, dose-dependent effects on pilocarpine-induced seizures in Sprague-Dawley rats. Brain Res. 1045, 38-44

https://doi.org/10.1016/j.brainres.2005.03.008

Bilecki W, Hollt V, Przewlocki R (2000): Acute delta-opioid receptor activation induces CREB phosphorylation in NG108-15 cells. Eur. J. Pharmacol. 390, 1-6 https://doi.org/10.1016/S0014-2999(00)00018-2

Calderon SN, Rothman RB, Porreca F, Flippen-Anderson JL, McNutt RW, Xu H, Smith LE, Bilsky EJ, Davis P, Rice KC (1994): Probes for narcotic receptor mediated phenomena19Synthesis of (+)-4-[ (alpha R)-alpha- ((2S,5R)-4-allyl-2,5-dimethyl1-piperazinyl)-3- methoxybenzyl]-N,N-diethylbenzamide (SNC 80): a highly selective, nonpeptide delta opioid receptor agonist. J. Med. Chem. 37, 2125-2128 https://doi.org/10.1021/jm00040a002

Calderon SN, Rice KC, Rothman RB, Porreca F, Flippen-Anderson JL, Kayakiri H, Xu H, Becketts K, Smith LE, Bilsky EJ, et al. (1997): Probes for narcotic receptor mediated phenomena23Synthesis, opioid receptor binding, and bioassay of the highly selective delta agonist (+)-4-[ (alpha R)-alpha((2S,5R)-4-Allyl-2,5-dimethyl-1-piperazinyl)-3-methoxybenzyl]- N,N-diethylbenzamide (SNC 80) and related novel nonpeptide delta opioid receptor ligands. J. Med. Chem. 40, 695-704 https://doi.org/10.1021/jm960319n

Chemin J, Nargeot J, Lory P (2002): Neuronal T-type alpha $1 \mathrm{H}$ calcium channels induce neuritogenesis and expression of high-voltage-activated calcium channels in the NG108-15 cell line. J. Neurosci. 22, 6856-6862 
Chung PC, Boehrer A, Stephan A, Matifas A, Scherrer G, Darcq E, Befort K, Kieffer BL (2015): Delta opioid receptors expressed in forebrain GABAergic neurons are responsible for SNC80induced seizures. Behav. Brain Res. 278, 429-43

Clementi E, Racchetti G, Zacchetti D, Panzeri MC, Meldolesi J (1992): Differential expression of markers and activities in a group of PC12 nerve cell clones. Eur. J. Neurosci. 4, 944-953

Connor M, Christie MD (1999): Opioid receptor signalling mechanisms. Clin. Exp. Pharmacol. Physiol. 26, 493-499 https://doi.org/10.1046/j.1440-1681.1999.03049.x

Corradi N, Borgonovo B, Clementi E, Bassetti M, Racchetti G, Consalez GG, Huttner WB, Meldolesi J, Rosa P (1996): Overall lack of regulated secretion in a PC12 variant cell clone. J. Biol. Chem. 271, 27116-27124 https://doi.org/10.1074/jbc.271.43.27116

Evans CJ, Keith DE, Jr, Morrison H, Magendzo K, Edwards RH (1992): Cloning of a delta opioid receptor by functional expression. Science 258, 1952-1955 https://doi.org/10.1126/science.1335167

Fawzi AB, Zhang H, Weig B, Hawes B, Graziano MP (1997): Nociceptin activation of the human ORL1 receptor expressed in Chinese hamster ovary cells: functional homology with opioid receptors. Eur. J. Pharmacol. 336, 233-242 https://doi.org/10.1016/S0014-2999(97)01227-2

Fujii H, Takahashi T, Nagase H (2013): Non-peptidic delta opioid receptor agonists and antagonists (2000-2012) Expert Opin. Ther. Pat. 23, 1181-1208

Fukami K, Inanobe S, Kanemaru K, Nakamura Y (2010): Phospholipase $\mathrm{C}$ is a key enzyme regulating intracellular calcium and modulating the phosphoinositide balance. Prog. Lipid Res. 49, 429-437

https://doi.org/10.1016/j.plipres.2010.06.001

Gaveriaux-Ruff C, Karchewski LA, Hever X, Matifas A, Kieffer BL (2008): Inflammatory pain is enhanced in delta opioid receptorknockout mice. Eur. J. Neurosci. 27, 2558-2567 https://doi.org/10.1111/j.1460-9568.2008.06223.x

Guo M, Cao D, Zhu S, Fu G, Wu Q, Liang J, Cao M (2015): Chronic exposure to morphine decreases the expression of EAAT3 via opioid receptors in hippocampal neurons. Brain Res. 1628, 40-49 https://doi.org/10.1016/j.brainres.2015.03.037

Hamprecht B (1977): Structural, electrophysiological, biochemical, and pharmacological properties of neuroblastoma-glioma cell hybrids in cell culture. Int. Rev. Cytol. 49, 99-170 https://doi.org/10.1016/S0074-7696(08)61948-8

Heiss A, Ammer H, Eisinger DA (2009): delta-Opioid receptorstimulated Akt signaling in neuroblastoma $\mathrm{x}$ glioma (NG10815) hybrid cells involves receptor tyrosine kinase-mediated PI3K activation. Exp. Cell Res. 315, 2115-2125 https://doi.org/10.1016/j.yexcr.2009.04.002

Hu Q, Shi YL (1997): Characterization of an inward-rectifying potassium current in NG108-15 neuroblastoma x glioma cells. Pflügers Arch. 433, 617-625

https://doi.org/10.1007/s004240050322

Jin W, Lee N, Loh H, Thayer S (1994): Opioids mobilize calcium from inositol 1,4,5-trisphosphate-sensitive stores in NG108-15 cells. J. Neurosci. 14, 1920-1929

Jutkiewicz EM, Rice KC, Woods JH, Winsauer PJ (2003): Effects of the delta-opioid receptor agonist SNC80 on learning rela- tive to its antidepressant-like effects in rats. Behav. Pharmacol. 14, 509-516 https://doi.org/10.1097/00008877-200311000-00003

Jutkiewicz EM, Eller EB, Folk JE, Rice KC, Traynor JR, Woods JH (2004): Delta-opioid agonists: differential efficacy and potency of SNC80, its 3-OH (SNC86) and 3-desoxy (SNC162) derivatives in Sprague-Dawley rats. J. Pharmacol. Exp. Ther. 309, 173-181 https://doi.org/10.1124/jpet.103.061242

Kamei J, Saitoh A, Oshsawa M, Suzuki T, Misawa M, Nagase H, Kasuya Y (1995): Antinociceptive effects of the selective nonpeptidic $\delta$ - opioid receptor agonist TAN-67 in diabetic mice. Eur. J. Pharmacol. 276, 135

https://doi.org/10.1016/0014-2999(95)00026-H

Kawaguchi A, Asano H, Matsushima K, Wada T, Yoshida S, Ichida S (2007): Enhancement of sodium current in NG108-15 cells during neural differentiation is mainly due to an increase in NaV1.7 expression. Neurochem. Res. 32, 1469-1475 https://doi.org/10.1007/s11064-007-9334-9

Kieffer BL, Befort K, Gaveriaux-Ruff C, Hirth CG (1992): The deltaopioid receptor: isolation of a cDNA by expression cloning and pharmacological characterization. Proc. Natl. Acad. Sci. U.S.A. 89, 12048-12052 https://doi.org/10.1073/pnas.89.24.12048

Lee S, Rosenberg CR, Musacchio JM (1988): Cross-dependence to opioid and alpha 2-adrenergic receptor agonists in NG108-15 cells. FASEB J. 2, 52-55 https://doi.org/10.1096/fasebj.2.1.2891579

Liu J, Tu H, Zhang D, Zheng H, Li YL (2012a): Voltage-gated sodium channel expression and action potential generation in differentiated NG108-15 cells. BMC Neurosci. 13, 129 https://doi.org/10.1186/1471-2202-13-129

Liu J, Tu H, Zhang D, Li YL (2012b): Changes of calcium channel mRNA, protein and current in NG108-15 cells after cell differentiation. BMC Neurosci. 423, 55-59 https://doi.org/10.1016/j.bbrc.2012.05.076

Loh HH, Smith AP (1990): Molecular characterization of opioid receptors. Annu Rev. Pharmacol. Toxicol. 30, 123-147 https://doi.org/10.1146/annurev.pa.30.040190.001011

Lukyanetz EA (1998): Diversity and properties of calcium channel types in NG108-15 hybrid cells. Neuroscience 87, 265-274 https://doi.org/10.1016/S0306-4522(98)00057-8

Lutfy K, Eitan S, Bryant CD, Yang YC, Saliminejad N, Walwyn W, Kieffer BL, Takeshima H, Carroll FI, Maidment NT, Evans CJ (2003): Buprenorphine-induced antinociception is mediated by mu-opioid receptors and compromised by concomitant activation of opioid receptor-like receptors. J. Neurosci. 23, 10331-10337

Ma W, Grant GM, Pancrazio JJ, Kao WY, Shaffer KM, Liu QY, Barker JL, Cohen NA, Stenger DA (1999): Kir 4.1 channel expression in neuroblastomaxglioma hybrid NG108-15 cell lineBrain research. Brain Res. Dev. Brain Res. 114, 127-134 https://doi.org/10.1016/S0165-3806(99)00015-2

McGee R, Simpson P, Christian C, Mata M, Nelson P, Nirenberg M (1978): Regulation of acetylcholine release from neuroblastoma x glioma hybrid cells. Proc. Natl. Acad. Sci. U.S.A. 75, 1314-1318 
https://doi.org/10.1073/pnas.75.3.1314

Metcalf MD, Yekkirala AS, Powers MD, Kitto KF, Fairbanks CA, Wilcox GL, Portoghese PS (2012): The delta opioid receptor agonist SNC80 selectively activates heteromeric mu-delta opioid receptors. ACS Chem. Neurosci. 3, 505-509 https://doi.org/10.1021/cn3000394

Negus SS, Gatch MB, Mello NK, Zhang X, Rice K (1998): Behavioral effects of the delta-selective opioid agonist SNC80 and related compounds in rhesus monkeys. J. Pharmacol. Exp. Ther. 286, 362-375

Pancrazio JJ, Ma W, Grant GM, Shaffer KM, Kao WY, Liu QY, Manos P, Barker JL, Stenger DA (1999): A role for inwardly rectifying $\mathrm{K}+$ channels in differentiation of NG108-15 neuroblastoma x glioma cells. J. Neurobiol. 38, 466-474 https://doi.org/10.1002/(SICI)1097-4695(199903)38:4<466::AID-NEU3 $>3.0 . \mathrm{CO} ; 2-8$

Portoghese PS, Sultana M, Takemori AE (1988): Naltrindole, a highly selective and potent non-peptide delta opioid receptor antagonist. Eur. J. Pharmacol. 146, 185-186 https://doi.org/10.1016/0014-2999(88)90502-X

Rajagopal S, Burton BK, Fields BL, El IO, Kamatchi GL (2017): Stimulatory and inhibitory effects of PKC isozymes are mediated by serine/threonine PKC sites of the Cav2.3alpha1 subunits. Arch. Biochem. Biophys. 621, 24-30 https://doi.org/10.1016/j.abb.2017.04.002

Rajagopal S, Fields BL, Burton BK, On C, Reeder AA, Kamatchi GL (2014): Inhibition of protein kinase C (PKC) response of voltage-gated calcium (Cav)2.2 channels expressed in Xenopus oocytes by Cavbeta subunits. Neuroscience 280, 1-9 https://doi.org/10.1016/j.neuroscience.2014.08.049

Remy C, Remy S, Beck H, Swandulla D, Hans M (2004): Modulation of voltage-dependent sodium channels by the delta-agonist SNC80 in acutely isolated rat hippocampal neurons. Neuropharmacology 47, 1102-1112

https://doi.org/10.1016/j.neuropharm.2004.06.034

Roerig SC, Loh HH, Law PY (1992): Identification of three separate guanine nucleotide-binding proteins that interact with the delta-opioid receptor in NG108-15 neuroblastoma $\mathrm{x}$ glioma hybrid cells. Mol. Pharmacol. 41, 822-831
Roy ML, Narahashi T (1992): Differential properties of tetrodotoxin-sensitive and tetrodotoxin-resistant sodium channels in rat dorsal root ganglion neurons. J. Neurosci. 12, 2104-2111

Shoji-Kasai Y, Yoshida A, Sato K, Hoshino T, Ogura A, Kondo S, Fujimoto Y, Kuwahara R, Kato R, Takahashi M (1992): Neurotransmitter release from synaptotagmin-deficient clonal variants of PC12 cells. Science 256, 1821-1823 https://doi.org/10.1126/science.256.5065.1820

Schanne FA, Moskal JR, Gupta RK (1989): Effect of lead on intracellular free calcium ion concentration in a presynaptic neuronal model: 19F-NMR study of NG108-15 cells. Brain Res. 503, 308-311 https://doi.org/10.1016/0006-8993(89)91680-6

Scheuer T (2011): Regulation of sodium channel activity by phosphorylation. Semin. Cell Dev. Biol. 22, 160-165 https://doi.org/10.1016/j.semcdb.2010.10.002

Spencer RJ, Jin W, Thayer SA, Chakrabarti S, Law PY, Loh HH (1997): Mobilization of Ca2 + from intracellular stores in transfected neuro2a cells by activation of multiple opioid receptor subtypes. Biochem. Pharmacol. 54, 809-818 https://doi.org/10.1016/S0006-2952(97)00243-8

Takemori AE, Sultana M, Nagase H, Portoghese PS (1992): Agonist and antagonist activities of ligands derived from naltrexone and oxymorphone. Life Sci. 50, 1491-1495 https://doi.org/10.1016/0024-3205(92)90138-F

Tojima T, Yamane Y, Takahashi M, Ito E (2000): Acquisition of neuronal proteins during differentiation of NG108-15 cells. Neurosci. Res. 37, 153-161 https://doi.org/10.1016/S0168-0102(00)00110-3

Ulens C, Daenens P, Tytgat J (1999): The dual modulation of GIRK1/ GIRK2 channels by opioid receptor ligands. Eur. J. Pharmacol. 385, 239-245 https://doi.org/10.1016/S0014-2999(99)00736-0

Vicente-Sanchez A, Segura L, Pradhan AA (2016): The delta opioid receptor tool box. Neuroscience 338, 145-159 https://doi.org/10.1016/j.neuroscience.2016.06.028

Received: March 2, 2018

Final version accepted: March 13, 2018

First published online: March 28, 2018 